\title{
Familial primary hypomagnesemia with normocalciuria and normocalcemia
}

INSERM

\section{Source}

INSERM. (1999). Orphanet: an online rare disease and orphan drug data base. Familial primary hypomagnesemia with normocalciuria and normocalcemia. ORPHA:34527

A form of familial primary hypomagnesemia (FPH), characterized by low serum magnesium $(\mathrm{Mg}$ ) values but inappropriate normal urinary $\mathrm{Mg}$ values (i.e. renal hypomagnesemia). The typical symptoms are weakness of the limbs, vertigo, headaches, seizures, brisk tendon reflexes and mild to moderate psychomotor delay. 